果 



\title{
Industriebetriebslehre: Anlagenwirtschaft
}

\author{
Von \\ Prof. Dr. rer. oec. habil. Dieter Slaby \\ und \\ Dipl.-Kfm. René Krasselt
}

R. Oldenbourg Verlag München Wien 


\section{Die Deutsche Bibliothek - CIP-Einheitsaufnahme}

\section{Slaby, Dieter:}

Industriebetriebslehre: Anlagenwirtschaft / von Dieter Slaby und René

Krasselt. - München ; Wien : Oldenbourg, 1998

ISBN 3-486-24486-8

C 1998 R. Oldenbourg Verlag

Rosenheimer Straße 145, D-81671 München

Telefon: (089) 45051-0, Internet: http://www.oldenbourg.de

Das Werk einschließlich aller Abbildungen ist urheberrechtlich geschützt. Jede Verwertung außerhalb der Grenzen des Urheberrechtsgesetzes ist ohne Zustimmung des Verlages unzulässig und strafbar. Das gilt insbesondere für Vervielfaltigungen, Übersetzungen, Mikroverfilmungen und die Einspeicherung und Bearbeitung in elektronischen Systemen.

Gedruckt auf saure- und chlorfreiem Papier

Gesamtherstellung: R. Oldenbourg Graphische Betriebe GmbH, Munchen 